\title{
Dynamics and Discriminatory Import Policy
}

Theodore To

CSG R Working Paper No. 07/ 98

May 1998
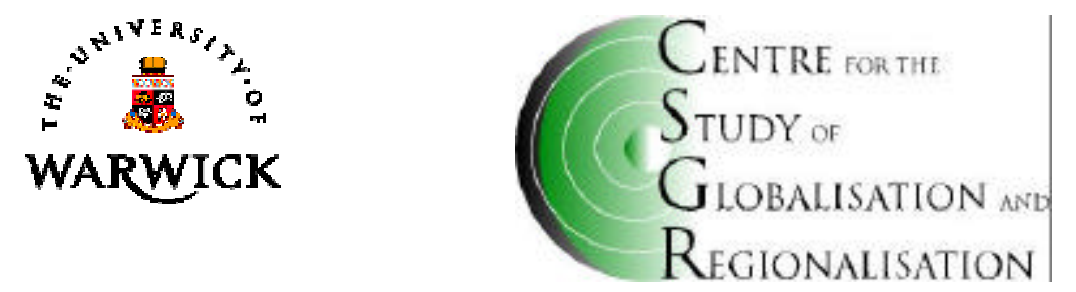


\title{
Dynamics and Discriminatory Import Policy
}

\section{Theodore To To*}

CSGR; University of Warwick

CSG R Working Paper No. 07/ 98

May 1998

\begin{abstract}
:
Although the General Agreement on Trade and Tariffs prohibits discriminatory import tariffs, GATT rules include means by which this prohibition can be circumvented. The previous literature use static models to show that discriminatory tariffs increase welfare. In a dynamic model, this is not necessarily true. For example, with consumer switching costs, current market share is valuable. In this case, discriminatory tariffs are higher for firms with a higher market share. In expectation of such policies, firms price less aggressively. If switching costs are significant relative to exporting country asymmetries then this adverse affect on incentives can result in lower importing country welfare. This suggests that it might be in the interests of importers to abide by the GATT MFN principle.
\end{abstract}

Keywords: discriminatory tariffs, endogenous protection, switching costs, market share.

JEL classification: F12, F13, L13

Address for correspondence:

Centre for the Study of Globalisation and Regionalisation,

University of Warwick

Coventry CV4 7AL, U.K.

Tel : (44 01203) 523049

Fax : (44 01203) 523032

E-mail:T.To@warwick.ac.uk.

*I thank V. Bhaskar, Jim Cassing, Esther Gal-Or, Jim Harrigan, Manfredi La Manna, Ray Reizman and two anonymous referees for helpful comments and suggestions. 


\section{Non-technical summary}

Although the GATT prohibits discriminatory tariffs, the means for such policy exists within GATT rules. For example, discriminatory tariffs can be imposed through the enforcement of anti-dumping duty laws. Similarly, programs such as the Generalized System of Preference and the Caribbean Basin Initiative are used by the US to provide preferential tariff treatment to LDCs. Further examples can be seen in the widespread use of 'voluntary' export restraint agreements. Hence there are numerous means by which the GATT's ban on discriminatory tariffs can be and is circumvented.

The literature on discriminatory tariffs under imperfect competition (Gatsios (1990) and Hwang and Mai (1991) suggests that such non-MFN tariffs can be beneficial for the importing country. This is because when intertemporal considerations are not considered, discriminatory tariffs allow greater tariffs to be levied on the 'stronger' (lost cost, better reputation, higher market share, etc.) country, minimizing the burden to consumers. However, intertemporal elements of policy can have important effects on the incentives of firms to compete.

I argue that one such imtertemporal consideration is the observable fact that firms value market-share. For profit maximizing firms, this can be due to persistence of market share over time (consumer switching costs) or learning as a result of past production (learning-by-doing). If current market share has a positive impact on future profits then discriminatory tariffs can have an adverse effect on the incentives of firms to compete aggressively. This is because a higher tariff will be levied on firms with higher market-shares. In anticipation of this penalty, market share is less valuable and firms compete less aggressively. When foreign producers are not very different, the benefit from discriminating based on cost differences is outweighed by the higher prices paid by consumers as a result of decreased competition. 


\section{Introduction}

Although the GATT prohibits discriminatory tariffs, the means for such policy exists within GATT rules. For example, discriminatory tariffs can be imposed through the enforcement of antidumping duty laws. Similarly, programs such as the Generalized System of Preference and the Caribbean Basin Initiative are used by the US to provide preferential tariff treatment to LDCs. Further examples can be seen in the widespread use of 'voluntary' export restraint agreements. Hence there are numerous means by which the GATT's ban on discriminatory tariffs can be and is circumvented.

The theory of discriminatory tariffs began with Meade (1955) and Viner (1950) who focus on discrimination by customs unions under perfect competition. Gatsios (1990) and Hwang and Mai (1991) consider discriminatory tariffs in an imperfectly competitive setting. Gatsios, and Hwang and Mai argue that high cost countries will face lower optimal tariffs. The intuition is that greater rents can be extracted from low cost countries.

As with many papers on strategic trade policy, these studies consider static models. Relying on static models can frequently lead to confusing results. For example, Brander and Spencer (1985) and Eaton and Grossman (1986) get contrasting export subsidy/tax results depending on whether firms compete in output or in prices. These conflicting results can be reconciled by introducing dynamics (To (1994a)), I examine discriminatory tariffs in a dynamic setting where market share is important.

There are several ways to model market share. I use consumer switching costs. With switching costs, it is costly for consumers (or wholesalers) to buy from one producer in one period and from another producer in the next. In an international setting, in addition to the usual 
description of switching costs, they can include transaction and information costs for importers. ${ }^{1}$ Market share is important to a firm when there are switching costs because after a consumer purchases from a firm, that consumer becomes bound to that firm and can thus be subjected to higher future prices by that firm. I show that the importing country imposes discriminatory tariffs which penalize market share and cost advantages in order to maximize the rents extracted from the foreign producers while minimizing the cost to the consumers. ${ }^{2}$ When asymmetries are relatively large, discriminatory tariffs have a negative impact on the welfare of the importing country because they reduce the value of market share. Other factors can mitigate this effect and are discussed later.

Another alternative is the standard 'learning-by-doing' framework (e.g., Baldwin and Krugman (1989), Dick (1991), Gruenspecht (1988) and To (1994b)). With learning-by-doing current market share is important because it lowers future production costs. Since learning-bydoing is important in many industries, I briefly discuss this.

\section{The Model}

I construct a dynamic model of imperfect international competition using a two-period duopoly model with consumer switching costs. Two exporting countries, with a single firm each, produce a differentiated product which is exported to an importing country which has no

\footnotetext{
${ }^{1}$ See Klemperer (1995) for a comprehensive survey and To (1994a) for a discussion of switching costs in an international context.

${ }^{2}$ The related strand of literature on endogenous protection (e.g., Bhagwati et al (1987), Blonigen (1995) and Grossman and Helpman (1994)) also assumes that government's have the ability to use discriminatory policy. The current paper is complementary to Grossman and Helpman as endogenous protection is derived as a result of the model and not assumed.
} 
production of its own. I follow Klemperer (1987) closely in my implementation of switching costs to examine sub-game perfect, optimal import policies with price competition.

In each period, $t=1,2$, each firm simultaneously chooses price $(p, j=0,1)$ and consumers from the importing country purchase from one of the firms. In addition, at the beginning of the second period, the government of the importing country chooses a tariff policy, $(\mathrm{T}, \mathrm{T})$. One can easily allow the importing government to impose tariffs in both periods but this adds nothing to the analysis and for simplicity is not considered. ${ }^{3}$

A different but important assumption is that the government cannot commit to a second period tariff in the first period. The common justification for this is that governments face a 'timeinconsistency problem.' While a government might want to pre-commit to a second period policy, this commitment is often not credible because once the second period arrives, governments will want to, and frequently can, pursue some alternative policy.

Consumers from the third country have mass one and are uniformly located on the interval $[0,1]$ and incur a transportation cost of one per unit of distance. 'Transportation costs' can be considered, in part or in whole, to be actual transportation costs and the good can be considered to be homogeneous. In each period, consumers inelastically demand one unit of the good, produced by either of the firms. Consumers' reservation values are sufficiently large that all consumers buy in equilibrium but not so large that firms would prefer to forgo all new consumers in order to exploit captured old consumers. Once a consumer has purchased from one supplier, it is too costly to switch to another supplier. This is standard and ensures that demand curves are differentiable. At the end of period 1 , mass $v \in(0,1]$ of uniformly and randomly chosen consumers leave the market and are replaced by new consumers. The turnover rate $v$ serves as a proxy for finite switching

\footnotetext{
${ }^{3}$ This possibility was included in a prior version of the paper.
} 
costs with large values of $v$ implying that switching costs are small 'on average.' Consumers minimize discounted expected price and transportation costs.

There are two exporting countries, 0 and 1, each with a single firm, 0 and 1, that maximize discounted profits and produce a spatially differentiated product. Firms 0 and 1 are located at 0 and 1 and have constant marginal costs $c^{0}$ and $c^{1}$. The government of the importing country maximizes discounted welfare, measured as the discounted sum of consumer surplus and tax receipts. I assume that the firms in the exporting countries and the government and consumers in the importing country have the same discount factor $\delta$.

\section{The Second Period}

Solving the game backwards, I begin with the consumers' second period problem.

\subsection{The Consumer's Problem}

In the second period, consumers minimize their second period costs given that they are either locked-in to some producer or that they are new consumers with no previous ties.

First consider the $v$ new consumers. If new consumer $i$ buys from firm 0 (or 1), i's total cost is firm 0's (or 1) price plus the tariff on firm 0 (or 1) plus i's transportation cost: $\mathrm{p}+\mathrm{i}+\mathrm{T}$ (or $\mathrm{p}$ $+(1-\mathrm{i})+\mathrm{T}){ }^{4}$ Let $\mathrm{i}^{*}$ be the new consumer that is indifferent between buying from firm 0 and from firm $1 ; i^{*}=(1+p-p+T-T) / 2$. As long as $|p-p+T-T| \leq 1,0 \leq i^{*} \leq 1$. Firm 0 sells to mass $v i^{*}$ new

\footnotetext{
${ }^{4}$ Note that I have assumed that tariffs are imposed directly on consumers. The results are
} 
consumers and firm 1 sells to mass $v\left(1-\mathrm{i}^{*}\right)$ new consumers. Now consider the $1-v$ old consumers. Since it is too costly to switch, old consumers buy from the same firm. Firm j sells to mass (1-v)q of the old consumers where $q$ is the number of consumers that bought from firm $\mathrm{j}$ in the first period.

Firm j's second period demand is equal to the sum of the new consumers that buy from $\mathrm{j}$ and the remaining old consumers that bought from $\mathrm{j}$ in the first period.

$$
q_{2}^{j}=(1-v) q_{1}^{j}+v\left[\frac{1+p_{2}^{k}-p_{2}^{j}+T_{2}^{k}-T_{2}^{j}}{2}\right]
$$

where $\mathrm{j}, \mathrm{k}=0,1$ and $\mathrm{j} \neq \mathrm{k}$.

\subsection{The Firm's Problem}

Firms maximize second period profits through choice of prices, given their market share from the first period, and the second period import policy chosen by the home government. Firm j's second period profits are:

$$
\pi_{2}^{j}=\left(p_{2}^{j}-c^{j}\right) q_{2}^{j}
$$

Taking the first order conditions and solving, the second period equilibrium price is:

$$
p_{2}^{j}=\frac{1}{v}+\frac{2 c^{j}+c^{k}}{3}+\frac{(1-\mathrm{v})\left(2 q_{1}^{j}-1\right)}{3 \mathrm{~V}}+\frac{T_{2}^{k}-T_{2}^{j}}{3}
$$

Price is increasing in both firm's costs, market share and tax advantage. Substituting the equilibrium price, yields second period output and second period profits.

identical if tariffs are imposed instead on the exporting firms. 


$$
\begin{aligned}
& q_{2}^{j}=\frac{1}{2}\left[1+\frac{(1-\mathrm{v})\left(2 q_{1}^{j}-1\right)}{3}+\frac{\mathrm{v}\left(c^{k}-c^{j}\right)}{3}+\frac{\mathrm{v}\left(T_{2}^{k}-T_{2}^{j}\right)}{3}\right] \\
& \pi_{2}^{j}=\frac{1}{2 v}\left[1+\frac{(1-\mathrm{v})\left(2 q_{1}^{j}-1\right)}{3}+\frac{\mathrm{v}\left(c^{k}-c^{j}\right)}{3}+\frac{\mathrm{v}\left(T_{2}^{k}-T_{2}^{j}\right)}{3}\right]^{2}
\end{aligned}
$$

Next, substitute equilibrium prices (3) into i ${ }^{*}$ to compute its equilibrium value.

$$
i^{*}=\frac{1}{2}+\frac{c^{1}-c^{0}}{6}-\frac{(1-\mathrm{V})\left(2 q_{1}^{0}-1\right)}{3 \mathrm{~V}}+\frac{T_{2}^{l}-T_{2}^{0}}{6}
$$

This will be required to solve the government's problem. Output and profits are increasing in market share, cost advantage and tax advantage. To get the non-discriminatory value for second period price, output, profits and $\mathrm{i}^{*}$, substitute $\mathrm{T}=\mathrm{T}$ into (3), (4), (5) and (6).

\subsection{The Home Country's Problem}

The home government maximizes second period welfare through its choice of import tariffs. The importing country's welfare is the sum of gross surplus and tax revenues minus total consumer costs. The total transportation cost of all of the new consumers that buy from firm 0 is $v\left(i^{*}\right)^{2} / 2$ and the total transportation cost of all of the old consumers that buy from 0 is $(1-v)(q)^{2} / 2$. Similarly, for firm 1 . Hence, home country welfare is: 


$$
\begin{gathered}
W_{2}=r+T_{2}^{0} q_{2}^{0}-\left(p_{2}^{0}+T_{2}^{0}\right) q_{2}^{0}-\frac{1-v}{2}\left(q_{1}^{0}\right)^{2}-\frac{v}{2}\left(i^{*}\right)^{2}+ \\
T_{2}^{l} q_{2}^{l}-\left(p_{2}^{l}+T_{2}^{l}\right) q_{2}^{l}-\frac{1-v}{2}\left(q_{1}^{l}\right)^{2}-\frac{v}{2}\left(1-i^{*}\right)^{2} \\
=r-p_{2}^{0} q_{2}^{0}-\frac{1-v}{2}\left(q_{1}^{0}\right)^{2}-\frac{v}{2}\left(i^{*}\right)^{2}-p_{2}^{l} q_{2}^{l}-\frac{1-v}{2}\left(q_{1}^{l}\right)^{2}-\frac{v}{2}\left(1-i^{*}\right)^{2} .
\end{gathered}
$$

Because of the nature of the Hotelling model of consumer demand, equal changes in the magnitudes of both tariffs result in a one-for-one tradeoff between consumer expenditures and government revenues. Thus as long as tariffs are not too high, consumer behavior depends only on the difference between the tariffs faced by country 0 and country 1 . This means that the importing country only needs to choose this difference and not the magnitudes of the tariffs.

Using the equilibrium values of price, output, profit and $i^{*}$, I compute the importing country's first order condition and then compute the equilibrium difference between tariffs.

$$
T_{2}^{l}-T_{2}^{0}=-\frac{2\left(c^{l}-c^{0}\right)}{5}-\frac{2(1-\mathrm{V})}{5 \mathrm{~V}}\left(2 q_{1}^{0}-1\right)
$$

Equation (8) implies that the home government should increase the tariff that a firm faces if it has a cost advantage or if it has a large market share. This result also provides a theoretical basis for models of endogenous protection which assume that tariffs are increasing in market share (examples include, Bhagwati et al (1987) and Blonigen (1995)).

Substituting this into price, output, profits and $\mathrm{i}^{*} \mathrm{I}$ get,

$$
p_{2}^{j}=\frac{1}{v}+\frac{4 c^{j}+c^{k}}{5}+\frac{1-v}{5 v}\left(2 q_{1}^{j}-1\right)
$$




$$
\begin{gathered}
q_{2}^{j}=\frac{1}{2}\left[1+\frac{\mathrm{v}\left(c^{k}-c^{j}\right)}{5}+\frac{1-\mathrm{v}}{5}\left(2 q_{1}^{j}-1\right)\right] \\
\pi_{2}^{j}=\frac{1}{2 v}\left[1+\frac{\mathrm{v}\left(c^{k}-c^{j}\right)}{5}+\frac{1-\mathrm{v}}{5}\left(2 q_{1}^{j}-1\right)\right]^{2} \\
i^{*}=\frac{1}{2}+\frac{c^{l}-c^{0}}{10}-\frac{2(1-\mathrm{v})\left(2 q_{1}^{0}-1\right)}{5 \mathrm{v}} .
\end{gathered}
$$

Notice that after substituting the welfare maximizing second period discriminatory tariffs, cost advantages and market share are less valuable than without discrimination (compare equation (11) to equation (5) when $\mathrm{T}=\mathrm{T}$ ). This maximizes the rents extracted from the exporting firms at the least cost to consumers. A firm with a cost and market share advantage earns greater profits and hence more rents can be extracted from that firm. This discriminatory tariff also reduces the disparity in direct consumer costs (i.e., price plus tariff), reducing consumer transportation costs incurred. $^{5}$

Second period welfare is increased by discriminatory import policy since, in general, the optimal policy, T-T, is non-zero. I show in the next section, however, that because the firm with the greater market share faces a higher tariff in the second period, market share is not as valuable in the first period and as a result, firms do not compete as vigorously for first period market share. With decreased first period competition, total discounted welfare in the importing country may fall due to the use of discriminatory tariffs.

\footnotetext{
${ }^{5}$ Transportation costs are minimized if $i^{*}=1 / 2$.
} 


\section{The First Period}

\subsection{The Consumers' Problem}

Consumers must decide which firm to purchase from, knowing how firms and governments will behave in the second period and knowing that if they are still in the market in the second period, they are 'locked-in' to whichever firm they purchase from. Each consumer i minimizes total discounted expected costs.

Consumer i's discounted expected cost from purchasing from firm 0 is her first period cost plus her total discounted expected second period cost: $p+i+\delta(1-v)(p+i+T)$. Similarly, if $i$ buys from firm 1 . Let $\mathrm{i}^{* *}$ be the consumer that is indifferent between purchasing from firm 0 and firm 1 .

$$
p_{1}^{0}+i^{* *}+\delta(1-\mathrm{V})\left(p_{2}^{0}+i^{* *}+T_{2}^{0}\right)=p_{1}^{1}+\left(1-i^{* *}\right)+\delta(1-\mathrm{V})\left(p_{2}^{1}+(1\right.
$$

Firm 0 's first period output is $q=i^{* *}$ since $i$ will buy from firm 0 if $i<i^{* *}$, and from firm 1 if $i>i^{* *}$. I substitute $\mathrm{q}$ for $\mathrm{i}^{* *}$ and (9) for $\mathrm{p}$ and then solve for firm 0's first period demand, $\mathrm{q}$. Firm 1's first period demand is $\mathrm{q}=1-\mathrm{q}$, so firm $\mathrm{j}$ 's first period demand is,

$$
q_{1}^{j}=\frac{1}{2}+\lambda\left(p_{1}^{k}-p_{1}^{j}\right)+\gamma \lambda\left(c^{k}-c^{j}\right)
$$

where, 


$$
\lambda=\frac{1}{2\left(1+\delta(1-v)\left(1+\frac{4(1-v)}{5 v}\right)\right)}, \gamma=\frac{\delta(1-v)}{5} .
$$

A non-standard feature of this model is that first period consumer demand depends on firm costs; costs enter the demand function through consumer expectations about the future price. ${ }^{6}$ Also notice that $\lambda=1 / 2$ if either $v=1$ or $\delta=0$ and $\lambda<1 / 2$ if both $v<1$ and $\delta>0 ; v=1$ corresponds to the case when there are no switching costs. Thus demand is more inelastic if there are switching costs and consumers are not myopic.

\subsection{The Firms' Problem}

Firms maximize discounted profits through choice of first period prices, given that it anticipates the second period outcome (i.e., the importing government's tariff policy and both firms' second period prices). Firm j's discounted profits are:

$$
\pi^{j}=\pi_{1}^{j}+\delta \pi_{2}^{j}=\left(p_{1}^{j}-c^{j}\right) q_{1}^{j}+\delta\left(p_{2}^{j}-c^{j}\right) q_{2}^{j}
$$

Firm j's first order condition is,

$$
\begin{aligned}
\frac{\partial \pi^{j}}{\partial p_{l}^{j}} & =-\left(2 \lambda-\frac{\delta \mu^{2}}{v}\right) p_{l}^{j}+\left(\frac{1}{2}-\frac{\delta \mu}{v}\right)+\left(\lambda-\frac{\delta \mu^{2}}{v}\right) p_{l}^{k} \\
& +\lambda c^{j}+\gamma\left(\lambda-\frac{\delta \mu^{2}}{v}\right)\left(c^{k}-c^{j}\right)-\frac{\delta \mu}{5}\left(c^{k}-c^{j}\right)=0
\end{aligned}
$$

\footnotetext{
${ }^{6}$ This is easily be eliminated if one assumes that consumers are myopic (i.e., $\delta=0$ ).
} 
where, $\mu=2 \lambda(1-v) / 5$.

Using this, the first period equilibrium prices are:

$$
p_{1}^{j}=\frac{\alpha}{1-\beta}+\frac{1}{1+\beta}\left(\beta c^{k}+c^{j}\right)+\frac{\gamma \beta-\eta}{1+\beta}\left(c^{k}-c^{j}\right)
$$

where

$$
\alpha=\frac{\frac{1}{2}-\frac{\delta \mu}{v}}{2 \lambda-\frac{\delta \mu^{2}}{v}}, \beta=\frac{\lambda-\frac{\delta \mu^{2}}{v}}{2 \lambda-\frac{\delta \mu^{2}}{v}}, \eta=\frac{\frac{\delta \mu}{5}}{2 \lambda-\frac{\delta \mu^{2}}{v}}
$$

It can be seen by simplifying the expression for $\beta$ that $\beta \in(0,1)$. After substituting prices, first period output is:

$$
q_{1}^{j}=\frac{1}{2}+\frac{\lambda[(1-\beta)(1+\gamma)+\eta]}{1+\beta}\left(c^{k}-c^{j}\right)
$$

so that firm j's period 1 output is increasing in its cost advantage.

Recall that second period tariffs are greater for the firm which successfully captures market share. As we will now see, this has an adverse effect on first period incentives, giving rise to the following Proposition.

Proposition 1: In period 1, if $\left|c^{1}-c^{0}\right|$ is not too large then, importing country welfare is greater under non-discriminatory tariff policy.

Proof: Consider first the case when $c^{1}=c^{0}=0$. In this case, $q=1 / 2$ and $p=\alpha /(1-\beta)$. Simplifying $p$, 


$$
p_{1}^{j}=\frac{5 v+\delta(1-v)(v+2)}{5 v} .
$$

The non-discriminatory tariffs first period price can be computed by solving the firm's profit maximization problem using (5) evaluated at $\mathrm{T}=\mathrm{T}$. This yields:

$$
p_{I^{\prime}}^{j}=\frac{3+\delta(1-\mathrm{v})}{3} .
$$

A comparison of the discriminatory price and the non-discriminatory price verifies that the discriminatory price is greater. With equal market share and identical costs, the second period discriminatory price and non-discriminatory price are both $1 / v$. Since price is greater in the first period and the same in the second period, welfare must be lower with discriminatory tariffs. Now since discriminatory prices and outputs are continuous in costs, welfare must be continuous in costs. This implies that for any $\mathrm{c}^{0}$ in some neighborhood of $\mathrm{c}^{1}$, welfare must be strictly lower with discriminatory tariffs.

Proposition 2 says that when foreign producers are relatively similar, discriminatory import policy actually reduces home country welfare. With consumer switching costs, there are two offsetting welfare effects. The first, static effect is a welfare gain which arises because greater rents can be extracted from the low-cost/high-market-share firm. The second, dynamic effect is a welfare loss which arises because firms expect market share to be penalized in the future. Thus market share is less valuable, leading firms to compete less aggressively in the first period. The overall welfare effect depends on which effect is more important. If there are large asymmetries between countries, then the static gains from discriminatory behavior become stronger and the negative incentive effect becomes less important. On the other hand, if asymmetries are relatively 
small, the static gains from discrimination are relatively small and thus the adverse dynamic effect overrides the static gain. When there are switching costs, discriminatory policy reduces the value of market share in the second period and firms do not compete as aggressively for market share in the first period, resulting in higher first period prices. On balance, welfare may increase or decrease depending on how important are cost asymmetries.

In addition to the magnitude of cost asymmetries, $\Delta c=\left|c^{1}-c^{0}\right|$, the overall welfare result also depends on the significance of switching costs, $v$. This can be seen by considering some parameter combination for which discriminatory policy is welfare reducing, $v$ and $\Delta c$. If we now reduce the significance of consumer switching costs by increasing $v$, it must be that for sufficiently large $v$, discriminatory policy increases welfare. To see this, note that in the limit as $v \rightarrow 1$, there are no switching costs and as a result the Gatsios (1990) and Hwang and Mai (1991) results must be true. Thus there is a tradeoff between the significance of switching costs and the magnitude of asymmetries so that if switching costs are very important, discriminatory tariffs may have a negative effect on importing country welfare even if cost asymmetries are large.

The existence of a domestic producer can affect the welfare results. Since discriminatory tariffs reduce the incentive for foreign firms to compete for market share in the first period, they have the beneficial effect of shifting first period rents to domestic producers. Thus there are two offsetting effects -- reduced first period competition, shifts foreign profits to the domestic producer but reduces consumer surplus. It can be shown with either a simple Bertrand or Cournot model that either effect can dominate. In particular, in a Bertrand model with linear demands and differentiated products, the effect of increased foreign prices will increase welfare only if foreign market share is sufficiently small. That is, when foreign imports are not insignificant, the loss in consumer surplus due to increased foreign prices can outweigh the value of increased domestic profits. Thus, although weakened, the negative welfare result can still hold. 
Finally, this analysis excludes the possibility that the home government can pre-commit to a second period import policy at the beginning of the first period. That is, suppose in the first period that the importing government announces a second period tariff schedule. If this announcement is enforceable (i.e., some constraint prevents the government from later changing its policy) then discriminatory policy must be welfare increasing since the government can always commit to a nondiscriminatory import policy.

Note that the discriminatory policies pursued by governments seem to accord with the prediction that duties will be greater for high market share exporters. For example, anti-dumping duties are imposed only if domestic industries suffer injury and domestic firms can be injured only if foreign producers have achieved significant import penetration. Similarly, VERs are only negotiated once foreign firms have captured a significant share of the market. Finally, programs such as the GSP and CBI specify an export limit in order to qualify for discounted tariffs. Of these examples, anti-dumping and VERs are purely reactive, however it might be argued that the GSP and CBI demonstrate some degree of commitment.

\section{Conclusion}

The General Agreement on Trade and Tariffs bans the use of discriminatory tariffs, but included in the GATT rules are means for circumventing this ban. Examples include the provision of preferential tariff treatment to less developed countries, the enforcement the GATT antidumping provisions, and the use of voluntary export restraints.

While there have been studies which argue that discriminatory tariffs increase importing country welfare (Gatsios (1990) and Hwang and Mai (1991)), these have used static models that 
do not consider important dynamic factors. One such dynamic factor is the idea that market share is important from one period to the next. I incorporated this idea by examining a model of international trade with consumer switching costs. Using this model, I showed that an importing country without the ability to commit to a long term policy will choose a discriminatory tariff schedule that penalizes low-cost producers and producers which have previously attained a high market share. Facing such a tariff schedule, foreign producers have a reduced incentive to compete aggressively for market share. Although this policy maximizes second period welfare, total discounted welfare may be reduced because in reducing the incentive for firms to capture market share, first period prices are higher.

With learning-by-doing, qualitatively identical results follow logically from earlier work. Consider, for example, a two period learning-by-doing model with constant marginal costs and where the exporting countries are initially symmetric (i.e., marginal costs are given by $\mathrm{c}=\mathrm{c}(\mathrm{q})$ where q is first period output). In the second period, by Gatsios (1990), and Hwang and Mai (1991), tariffs are higher for the exporter with the lower marginal cost. Since firms are initially symmetric, this is the firm which made greater sales in the first period. As a result their first period incentive to price aggressively is reduced. Thus with learning-by-doing, discriminatory tariffs also have a negative effect on first period incentives. ${ }^{7}$ This negative first period effect has a further negative effect since second period costs, and as a result, prices can be higher.

Choi (1995) bears some similarity to the current work. In his three stage game, firms first choose their production technology. In the second stage, the government of the importing country chooses its tariff policy. Finally, in the last stage, firms compete in output. With discriminatory

\footnotetext{
${ }^{7}$ If the government chooses both first and second period policy, second period policy can be to subsidize imports (see Gatsios (1989)). However, this does not eliminate the second period policy's negative effect on incentives.
} 
tariffs, the firm which chooses the low cost technology faces a higher tariff. This discourages the adoption of more efficient technologies and as a result, prices are higher than under MFN tariffs. Like Choi, with the current model, firms make an initial investment (in market share). Discriminatory tariffs reduce the value of this investment, resulting in 'underinvestment.' One important difference between the current work and Choi is that he assumes symmetry at the outset. That is, prior to making their technology choice, firms are completely symmetric. Thus if firms are initially asymmetric (e.g., one firm has an initial cost advantage) then discriminatory policy will also have a welfare increasing effect which is stronger the greater the asymmetry.

To conclude, the GATT provides a legal framework by which governments can credibly commit to a policy of non-discrimination, however, it also provides 'escape clauses' by which governments can discriminate. When dynamics are important, discriminatory policy can have a negative incentive effect which can lead to reduced welfare, even though in a static sense, such a policy may be welfare maximizing. Like the other literature on imperfect competition and trade, the results are sensitive to assumptions. Thus governments should carefully consider a decision to circumvent the GATT ban on discriminatory tariffs. 


\section{References}

Baldwin, Robert and Paul Krugman, 1989, "Market Access and International Competition: A Simulation Study of 16K Random Access Memories," in Empirical Research in International Trade, ed. R. Feenstra, MIT Press.

Bhagwati, Jagdish, Richard Brecher, Elias Dinopoulos, and T.N. Srinavasan, "Quid Pro Quo Foreign Investment and Welfare," Journal of Development Economics, 27, 127-138.

Blonigen, Bruce, 1995, "Endogenous Protection, Tariff-Jumping and Protection-Building Trade," University of Oregon working paper.

Brander, James and Barbara Spencer, 1985, "Export Subsidies and International Market Share Rivalry," Journal of International Economics, 18, 83-100.

Choi, Jay Pil, 1995, "Optimal Tariffs and the Choice of Technology: Discriminatory Tariffs vs. the ‘Most Favored Nation' Clause," Journal of International Economics, 38, 143-160.

Dick, Andrew R., 1991, "Learning-by-Doing and Dumping in the Semiconductor Industry," Journal of Law and Economics, 34, 133-159.

Eaton, Jonathan and Gene Grossman, 1986, "Optimal Trade and Industrial Policy Under Oligopoly," Quarterly Journal of Economics, 383-406.

Gatsios, K., 1989, "Imperfect Competition and International Trade," in F. Hahn (ed.) The Economics of Missing Markets, Information, and Games, Oxford: Oxford University Press.

Gatsios, K., 1990, "Preferential Tariffs and the Most Favoured Nation Principle: A Note," Journal of International Economics, 28, 365-373.

Grossman, Gene and Elhanan Helpman, 1994, "Foreign Investment with Endogenous Protection," NBER Working Paper \#4876. 
Gruenspecht, Howard, 1988, "Dumping and Dynamic Competition," Journal of International Economics, 25, 225-248.

Hwang, H. and C. Mai, 1991, "Optimum Discriminatory Tariffs under Oligopolistic Competition," Canadian Journal of Economics, 24, 1991.

Klemperer, Paul, 1987, "The Competitiveness of Markets with Switching Costs," Rand Journal of Economics, 18, 138-150.

Klemperer, Paul, 1995, "Competition when Consumers Have Switching Costs: An Overview with Applications to Industrial Organization, Macroeconomics, and International Trade," Review of Economic Studies, 62, 515-539.

Meade, J., 1955, The Theory of Customs Unions, North-Holland, Amsterdam.

To, Theodore, 1994a, "Export Subsidies with Oligopoly and Switching Costs," Journal of International Economics, 37, 97-110.

To, Theodore, 1994b, "Infant Industry Protection with Learning-by-Doing and Oligopoly," Journal of International Trade and Economic Development, 3, 199-212.

Viner, J., 1950, The Customs Union Issue, Carnegie Endowment for International Peace, New York. 